\title{
Macrobrachium sbordonii (Decapoda: Palaemonidae), a new stygobitic species of freshwater prawn from Chiapas Mexico
}

\author{
LUIS M. MEJÍA-ORTÍZ ${ }^{1,4}$, FABIOLA BALDARI² \& MARILÚ LÓPEZ-MEJÍA ${ }^{3}$ \\ ${ }^{1}$ Laboratorio de Bioespeleología y Carcinología, ${ }^{3}$ Laboratorio de Biología Evolutiva y Genética de Poblaciones, Universidad de \\ Quintana Roo-Cozumel (UQROO-Cozumel). DDS, Dpto. Ciencias y Humanidades, Avenida Andrés Quintana Roo s/n, Cozumel, \\ Quintana Roo, México.E-mail: luismejia@uqroo.mx \& marlopez@uqroo.mx \\ ${ }^{2}$ Dipartimento di Biología, Universitá di Roma “Tor Vergata”. Vía Della Recerca Scientifica I-00133 Roma Italy, E-mail: bal- \\ dari@uniroma2.it \\ ${ }^{4}$ Corresponding author. E-mail: luismejia@uqroo.mx
}

\begin{abstract}
The fourth stygobitic species of the genus Macrobrachium from caves in America is described. Macrobrachium sbordonii, a new species inhabiting a cave of Chiapas Mexico, is similar to M. villalobosi, M. acheronthium and M. catonium in exhibiting reduced eyes, unpigmentated body and enlargement of ambulatory appendages. It differs from these in length of the first pereiopod and relative proportions of the articles of the second pereiopod, pigmentation degrees on eyes, number of rostral spines, proportions of the scaphocerite, and relative proportions of the carpus and propodus of the first pereiopod. Macrobrachium sbordonii occurs in the inner lake of the Sistema de La Lucha, a cave located near the Chiapas-Oaxaca border, in the Tehuantepec Itsmus Region.
\end{abstract}

Key words: Stygobitic Palaemonid, central America

\section{Resumen}

Se describe la cuarta especie estigobia en América del género Macrobrachium en cuevas. Macrobrachium sbordonii nueva especie habita en una cueva de Chiapas, México; es similar a M. villalobosi, M. acheronthium y M. catonium por exhibir ojos reducidos, cuerpo despigmentado y alargamiento de los apéndices ambulatorios, pero difiere de éstos en la longitud del primer pereiópodo y las proporciones relativas de los artejos del segundo pereiópodo, los grados de pigmentación del ojo, el número de espinas rostrales, la proporción del escafocerito y la proporción relativa del carpus y propodio del primer pereiópodo. Macrobrachium sbordonii vive en el lago terminal del Sistema de la Lucha, estado de Chiapas, cerca de los límites con Oaxaca, dentro de la región del Istmo de Tehuantepec.

\section{Introduction}

Ten Macrobrachium species adapted to cave life are known so far, including Macrobrachium lingyunense Li, Cai \& Clarke, 2006, the last described species. The remaining species are following: Macrobrachium cavernicola (Kemp, 1924), Macrobrachium villalobosi Hobbs, 1973; Macrobrachium lucifungum Holthuis, 1974; Macrobrachium acherontium Holthuis, 1977; Macrobrachium microps Holthuis, 1978; Macrobrachium poeti Holthuis, 1984; Macrobrachium gua Chong 1989; Macrobrachium catonium Hobbs \& Hobbs, 1995; and Macrobrachium miyakoense Komai \& Fujita, 2005. 
Until now, sixteen species of Macrobrachium have been recorded in Mexico. Among these, two species have been reported from cave environment, i.e. M. villalobosi and M. acherontium (Villalobos \& Álvarez, 1999; Román et al., 2000; Mejía et al., 2003). In this paper, a new stygobitic species is described. It occurs in the Cueva de la Lucha western of Chiapas, in the Malapaso Region (fig. 1). The relationships of the new species with other subterranean species from America are discussed.

The type specimens are deposited in the National Crustacean Collection (CNCR) of the Instituto de Biología, Universidad Nacional Autónoma de México, Mexico City, in the Colección de Crustáceos de Referencia of Lab. de Bioespeleología y Carcinología UQROO-Cozumel (BC-UQROO), and in Collection of the Dipartimento di Biologia, Universitá degli Studi di Roma "Tor Vergata" (DB-Tor Vergata). The description is based on holotype and allotype material.
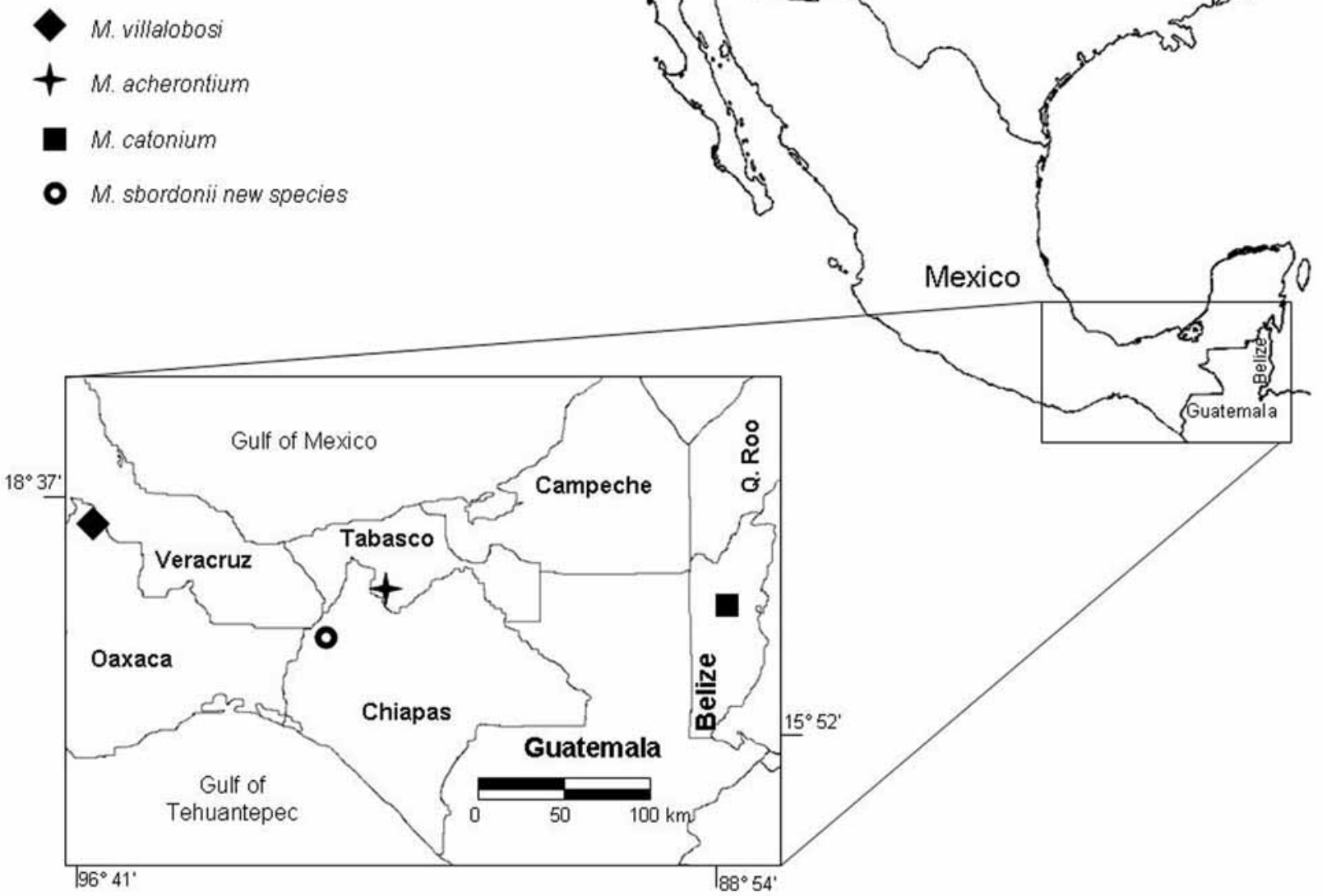

FIGURE 1. Distribution of the stygobitic species of Macrobrachium in America.

\section{Systematics}

\section{Macrobrachium sbordonii new species}

figs. $2-4$

Holotype. Male, Carapace length $(C L)=18.2 \mathrm{~mm}$, May 1988; R. De Cristofaro, E. Franco and C. De Monte

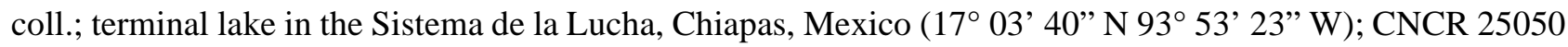
Allotype.- Female, $\mathrm{CL}=17.5 \mathrm{~mm}, 21$ April 1987; E. Franco, R. De Cristofaro coll., same locality as holotype; CNCR 25051. 
Paratypes. 1 male, $C L=18.7 \mathrm{~mm} 3$ females, $C L=20-21,5 \mathrm{~mm}$; May 1988; R. De Cristofaro, E. Franco and C. De Monte, coll.; CNCR 25052. 1 male $C L=17.9 \mathrm{~mm}, 3$ females, $C L=17.8-19.3 \mathrm{~mm}$; 21 April 1987; E. Franco, R. De Cristofaro coll.; BC-UQROO-160. 2 males CL=16-19.5 mm, 12 females CL=14.7-22 mm; 10 April 1986; C. Giudici, M. Diana coll. (DB-Tor Vergata). All paratypes were collected in the type locality.

Description. Medium sized prawn, maximum total length $39.3 \mathrm{~mm}$. Rostrum short, curved anteriorly, tip not reaching the distal border of scaphocerite but surpassing the third article of antennular peduncle; dorsal margin bearing 7 teeth, 1 in postorbital position, two teeth on ventral margin (fig. 2). Live M. sbordonii new species is white, without pigment in the body.

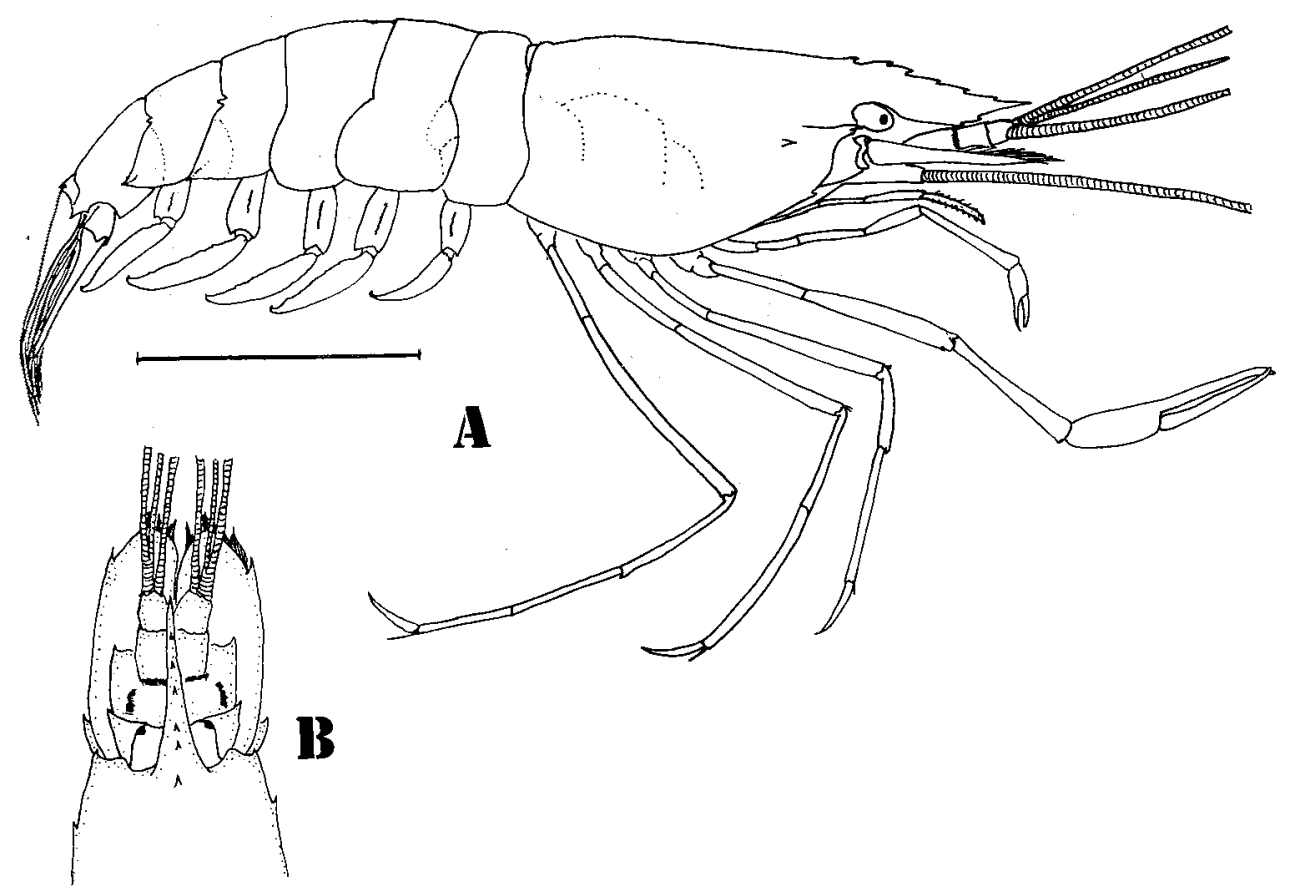

FIGURE 2. Macrobrachium sbordonii new species Male holotype CNCR 25050 A, lateral view; B Dorsal view. Scale bar represent $10 \mathrm{~mm}$.

Carapace smooth, maximum length $17 \mathrm{~mm}$, with antennal spine smaller than hepatic spine. Branchiostegal groove shallow.

Abdomen smooth, pleura of first three somites broadly rounded (fig. 2). Posteroventral margin of fourth and fifth pleura acute, all pleura bearing setae on ventral border. Sixth somite 1.3 times as long as fifth. Telson 1.2 times longer than sixth somite, shorter than uropodal rami; bearing two pairs of dorsal spines, first pair in distal fifth, second pair in middle section of telson; posterior margin broadly triangular bearing two pairs of lateral spines, inner pair 5 times longer than external one, with plumose setae between inner spines (Fig. 4G).

Eyes reduced, cornea with a small apical black point, this point bearing facets.

Antennules with acute stylocerite reaching proximal third of first peduncular segment (fig. 3C). First antennular segment with acute distolateral spine and concave depression to fit eye. Second antennular segment cylindrical, with sinuous distal margin and lateral row of long setae.

Antennae with basicerite bearing large spine on internal margin. Scaphocerite 2.4 times as long as wide, distolateral spine short, widely separated from distal margin of main blade (fig. 3A).

Mandibles with 3-segmented palp, first segment the shortest, second and third segments of equal length; incisor process with 3 conical teeth, molar process with 5 wide, rounded teeth on mesial border (fig. 4A).

Maxillules with bilobed palp, distal lobe slender, with three setae on the tip, proximal lobe blunt with three thick setae; anterior lacinia approximately oval, with three long setae on mesial margin, distal margin with five thick spines and a row of fine setae, lateral margin straight, with few setae; posterior lacinia tapering distally, curved inwards, distal half covered with setae (fig. 4B). 


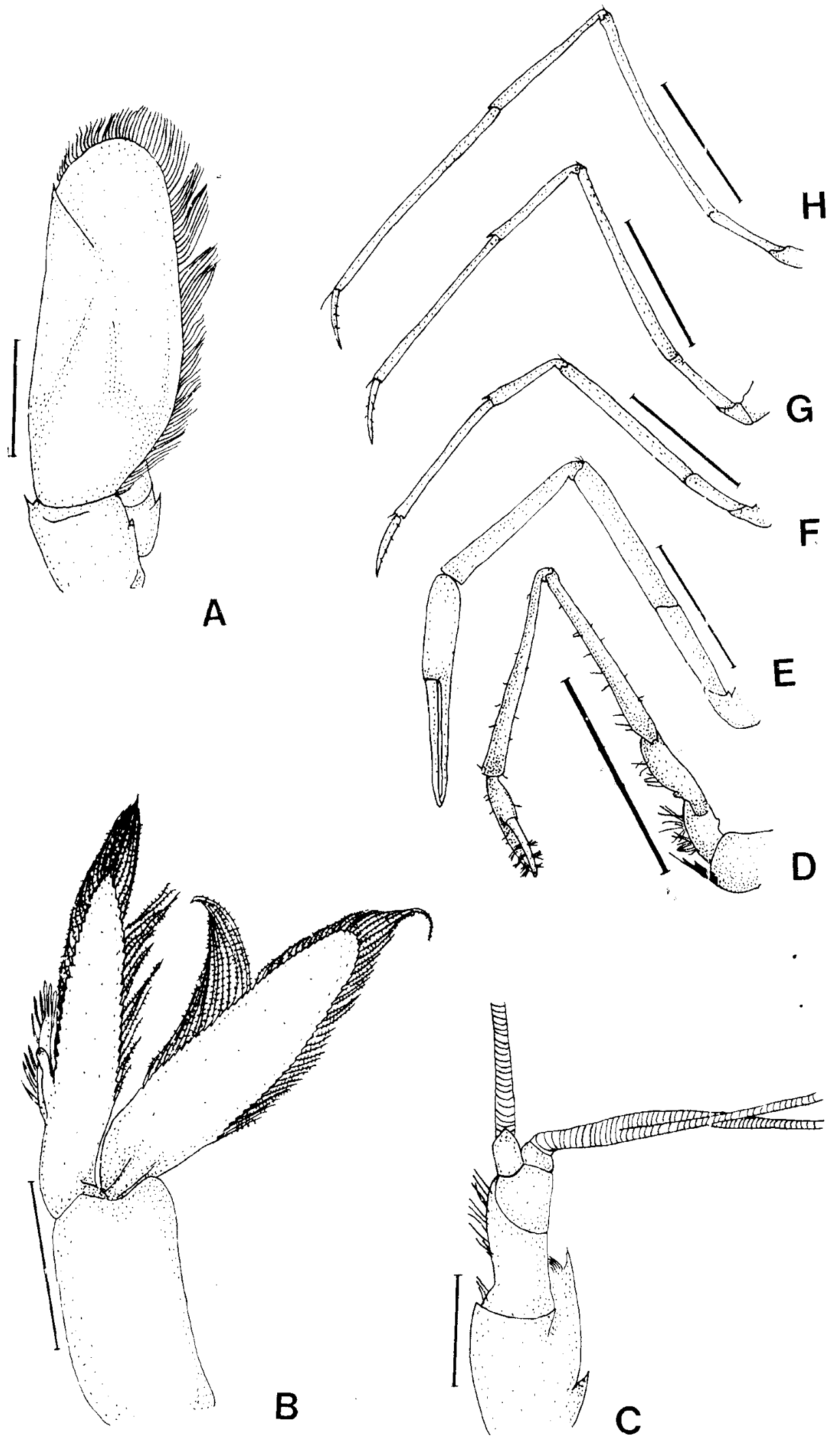

FIGURE 3. Macrobrachium sbordonii new species, male holotype CNCR 25050. A, distal portion of antennal peduncle; B, appendix masculina on second pleopod; C, distal portion of antennular peduncle; D-H, first through fifth pereiopods, respectively. Scale bars represent: A-C, $2 \mathrm{~mm}$; D-H, $5 \mathrm{~mm}$. 

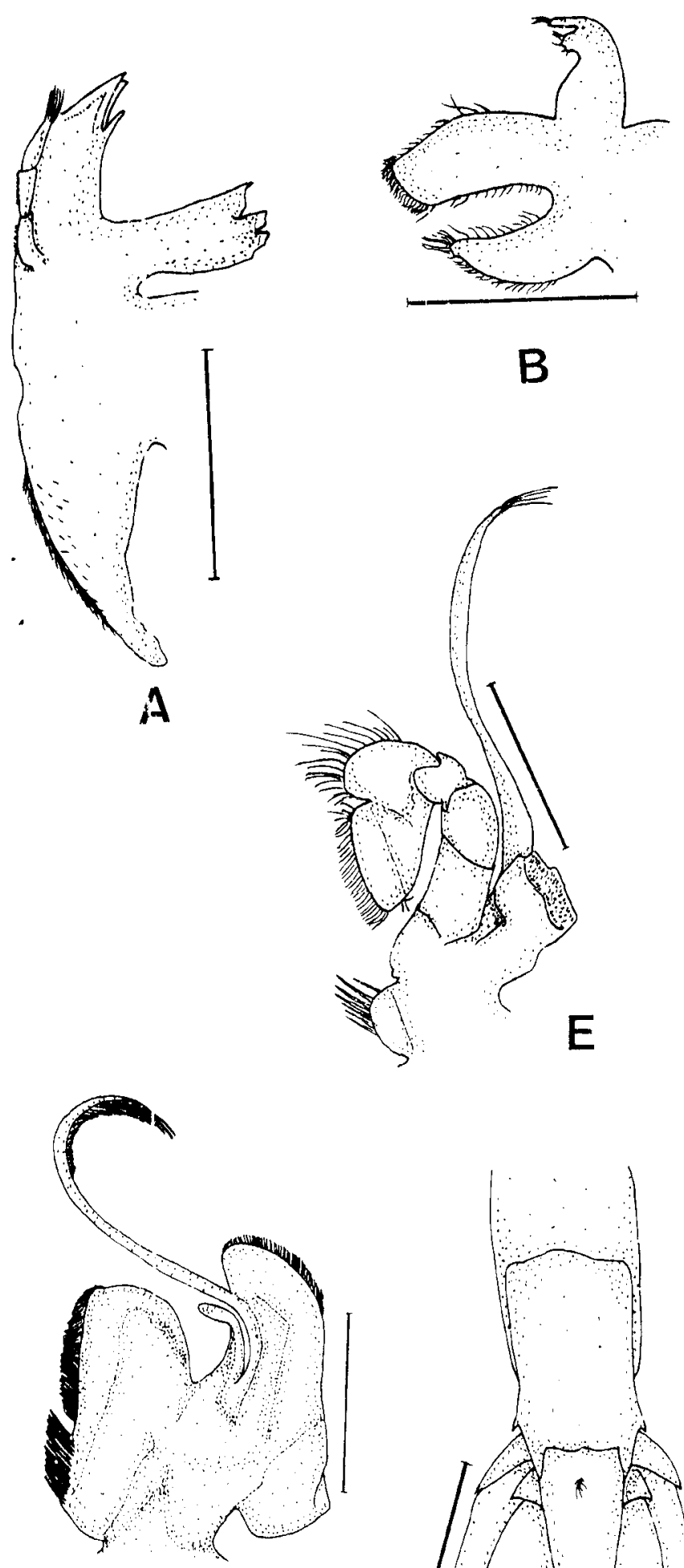

D
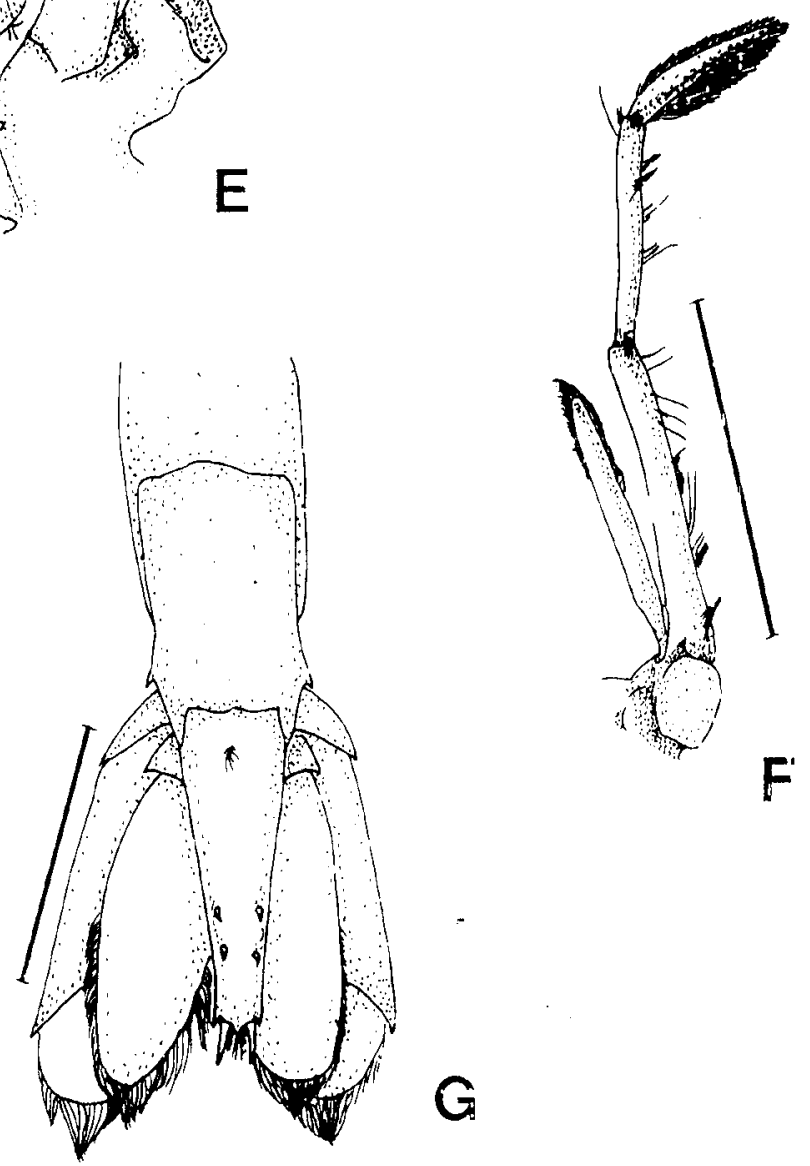

FIGURE 4. Macrobrachium sbordonii new species, male holotype CNCR 25050. A, right mandible; B, right maxillule; $\mathrm{C}$, right maxilla; D, first maxilliped; E, second maxilliped; F, third maxilliped; G, telson and uropods. Scale bars represent: A-E, $2 \mathrm{~mm}$; F-G, 5 mm. 
Maxillae with scaphognathite bordered with plumose setae, anterior lobe narrower and longer than posterior one; palp lack of setae, tapering distally, strongly curved inwards; endite bilobed, divided by incision along distal third, both lobes with tuft of setae on the tip (fig. 4C).

First maxilliped with bilobed endite, bearing marginal and submarginal setae along margin, and row of setae on surface of distal lobe. Exopod slender, 6 times as long as palp, distal third bearing long setae; palp simple, with two thick setae, shorter than endite; caridean lobe large, fused to base of exopod, bearing long, plumose setae all along margin; epipodite trapezoidal (fig. 4D).

Second maxilliped subpediform, podobranch present, well developed; endopodite 4-segmented, distal 2 segments oriented mesially, gnathal border with marginal setae and spines and submarginal setae; exopodite slender, almost twice as long as endopodite, tip bearing long, plumose setae (fig. 4E).

Third maxilliped pediform, slender, reaching beyond basal portion of antennal flagellum; arthrobranch present, well developed; coxa with rounded lateral projection (fig. 4F). Endopodite 3-segmented, with abundant setae, becoming denser distally; first segment slender, 1.3 times as long as second segment; second segment 1.3 times as long as third, distal margin ending in nail. Exopodite slender, flat, as short as first segment of endopodite, bearing long setae distally.

First pereiopods slender, smooth, with scarcity tufts of setae on both fingers. Tip of fingers surpassing distal margin of scaphocerite; palm slightly compressed, as long as dactylus; carpus 4.5 times palm length, 1.12 times merus length (fig. 3D).

Second pair of pereiopods slightly equal in size, without spines. Palm cylindrical, 3 times as long as wide, with disperse tufts of setae, 0.75 times dactylus length; carpus 2 times palm length, 1.09 times as long as merus; ischium 0.72 times merus length. Fingers not gaping, elongate, cutting margins covered with tufts of setae, fixed finger and dactylus without teeth (fig. 3E).

Propodus and dactylus of third pereiopod with several tufts of short setae. One row of three tufts of setae on inner border of propodus, distal pair of tufts of setae on articulation with dactylus and two rows of 7 and 9 movible spines on inner margin of propodus 1 pairs distally in articulation with dactylus. Propodus 2.5 times length of dactylus, 2 times carpus length (fig. 3F).

Fourth pereiopods, sparsely pilose; propodus 3 times dactylus length, 1.85 times as long as carpus; with one row of three movable spines on inner border of propodus, one pair of spines and tufts of setae on propodus-dactylus articulation (fig. 3G).

Fifth pair of pereiopods the longest. Propodus and carpus pilose; one longitudinal row of 4 movable spines, 1 spine on propodus-dactylus articulation; propodus 4 times dactylus length, 1.6 times carpus length (fig. 3H).

Appendix masculina 1.7 times length of appendix interna, inner margin with 12 pairs of spines (fig. 3B).

Etymology. The specific name is given in honor of Professor Valerio Sbordoni, Tor Vergata University of Roma Italy, an indefatigable biospeleologist providing an outstanding contribution to the knowledge of the cave fauna of Chiapas.

Habitat. This species lives in the Cueva de La Lucha, a cave system situated at the northeastern edge of the Selva del Mercadito, a large limestone area at the border region of Chiapas and Oaxaca in the southern Mexico. The cave, explored and visited in the course of various expeditions led by Professor V. Sbordoni, is described by Gambari \& Topani (1986). The whole cave system is about $1300 \mathrm{~m}$ long, interrupted after $650 \mathrm{~m}$ by a large doline (sotano), 220 metres deep. A subterranean river flows into a large lake in the terminal cave section, where the new species lives. This lake has a deepest part of $5 \mathrm{~m}$, with a maximum diameter of $140 \mathrm{~m}$. The water temperature measured at the time of collection was $19^{\circ} \mathrm{C}$ (Sbordoni et al., 1987). The cave river is subjected to impressive flooding during the wet season.

A rich cave fauna inhabits this cave (Sbordoni et al., 1986, 1987; Sbordoni \& Lucarelli, 1989-90). Other notable aquatic taxa include a freshwater crab, a new species of troglomorphic crayfish of the genus Procambarus (description in process), and the stygobitic fish Rhamdia laluchensis Weber, Allegrucci \& Sbordoni, 2003. 


\section{Discussion}

Geographically, Macrobrachium sbordonii new species is more closeness to $M$. acherontium, since there are more distance with $M$. villalobosi and M. catonium. Macrobrachium villalobosi occurs in two caves at the northern area of Oaxaca, $339 \mathrm{~km}$ to the northeast; M. acheronthium lives in the Cocona Grootes, $121 \mathrm{~km}$ to the north; and M. catonium inhabits a cave at Cayo District of Belize, $627 \mathrm{~km}$ to the south (Fig. 1).

TABLE 1. Comparison among the Macrobrachium stygobitic species from America.

\begin{tabular}{|c|c|c|}
\hline & M. villalobosi & M. acherontium \\
\hline Rostrum & $\begin{array}{l}\text { 9-11(2)/2, reaching beyond the distal } \\
\text { margin of scaphocerite and teeth are } \\
\text { simple. }\end{array}$ & $\begin{array}{l}8-11(3) / 3 \text {, reaching the distal margin of scaphocerite, } \\
\text { all teeth are simple. }\end{array}$ \\
\hline Scaphocerite & 3 times as long as width & 2.7 times as long as width \\
\hline Telson & $\begin{array}{l}1.4 \text { times the length of sixth abdominal } \\
\text { somite }\end{array}$ & 1.2 times the length of sixth abdominal somite \\
\hline Eyes & Absent & Globular, cornea with facets over pigmented area. \\
\hline First pereipods & $\begin{array}{l}\text { Reaching the first third of carpus length } \\
\text { of second pereiopods. Carpus two times } \\
\text { the length of chelae }\end{array}$ & $\begin{array}{l}\text { Reaching the last third of carpus length of second } \\
\text { pereiopods. Carpus less of two times the length of } \\
\text { chelae. }\end{array}$ \\
\hline $\begin{array}{l}\text { Second pair of } \\
\text { pereiopods }\end{array}$ & $\begin{array}{l}\text { Smooth with scattered setae; ischium } \\
0.76 \text { as long as merus, } 0.5 \text { as long as } \\
\text { carpus and chela. } \\
\text { Length } 0.56 \text { times of total length. }\end{array}$ & $\begin{array}{l}\text { Smooth with scattered setae; ischium } 0.93 \text { as long as } \\
\text { merus, } 0.75 \text { as long as carpus, and } 0.63 \text { as long as chela. } \\
\text { Length } 0.50 \text { times of total length. }\end{array}$ \\
\hline Appendix masculina & $\begin{array}{l}\text { Aproximately } 1.85 \text { times the length of } \\
\text { appendix interna, with } 14 \text { pairs of } \\
\text { spines. }\end{array}$ & $\begin{array}{l}\text { Almost } 2 \text { times as long as appendix interna, with } 21 \\
\text { pairs of spines }\end{array}$ \\
\hline
\end{tabular}

continued.

\begin{tabular}{|c|c|c|}
\hline & M. catonium & M. sbordonii nov. sp. \\
\hline Rostrum & $\begin{array}{l}6-9(1-2) / 2-5, \text { not reaching the distal margin of } \\
\text { scaphocerite, } 3 \text { teeth bispinous on dorsal mar- } \\
\text { gin. }\end{array}$ & $\begin{array}{l}6-8(1) / 2, \text { not reaching the distal margin of } \\
\text { scaphocerite, all teeth are simple. }\end{array}$ \\
\hline Scaphocerite & 2.5 times as long as width & 2.4 times as long as width \\
\hline Telson & 1.2 times the length of sixth abdominal somite & 1.2 times the length of sixth abdominal somite \\
\hline Eyes & $\begin{array}{l}\text { Large, apical black to purplish pigment spot; } \\
\text { cornea over pigmented area lacking facets }\end{array}$ & $\begin{array}{l}\text { Reduced with a black point, cornea with facets } \\
\text { in this point }\end{array}$ \\
\hline First pereipods & $\begin{array}{l}\text { Reaching the half of carpus length of second } \\
\text { pereiopods. Carpus } 1.8 \text { times the length of } \\
\text { chelae. }\end{array}$ & $\begin{array}{l}\text { Reaching the chela of second pereiopods. Car- } \\
\text { pus } 2 \text { times the length of chelae. }\end{array}$ \\
\hline $\begin{array}{l}\text { Second pair of } \\
\text { pereiopods }\end{array}$ & $\begin{array}{l}\text { Smooth with scattered setae; ischium } 0.75 \text { as } \\
\text { long as merus, } 0.64 \text { as long as carpus and } 0.75 \\
\text { as long as chelae. Length } 0.46 \text { times of total } \\
\text { length. }\end{array}$ & $\begin{array}{l}\text { Smooth with scattered setae; ischium } 0.58 \text { as } \\
\text { long as merus, } 0.72 \text { as long as carpus and } 0.44 \\
\text { as long as chelae. Length } 0.56 \text { times of total } \\
\text { length. }\end{array}$ \\
\hline Appendix masculina & $\begin{array}{l}\text { Aproximately } 1.7 \text { times as long as appendix } \\
\text { interna, with } 8 \text { pair of spines. }\end{array}$ & $\begin{array}{l}\text { Aproximately } 1.75 \text { times as long as appendix } \\
\text { interna with } 12 \text { pair of spines. }\end{array}$ \\
\hline
\end{tabular}

These four species which exclusively inhabit underwater environment have elongated pereiopods and $M$. acherontium also has pigmented body and eyes. Macrobrachium villalobosi shows more defined stygobiont 
characteristics such as unpigmented body, elongated appendages, and reduced and unpigmented eyes. Macrobrachium sbordonii new species also shows stygobiont features by having unpigmentated body but the eyes still have a small black point.

The morphological differences between the new species and the other three American cave species are the ornamentation of the rostrum, the proportions of the articles of the first and the second pereiopods, the length of the first pereiopod in relation to the second one, and the proportion between the length of the appendix masculina and the length of the appendix interna, as well as the disposition and the number of the setae on the appendix masculina (table 1). However, some characters of this new species are more similar to M. catonium as shown in table 1 .

Regarding to cave adaptations, we can found different adaptation degrees to this environment. In this case, from the four species M. sbordonii is probably the second or third species together with M. catonium that invaded the cave environment because both species still have a black point in the eyes, after of $M$. villalobosi that show more regresive adaptations to cave life from four species and the last $M$. acherontium that still have eyes with a well pigmentated cornea.

Therefore these four cave species, there are other Macrobrachium species in this area that live in adjacents rivers and also show abbreviated development, Macrobrachium totonacum Mejía, Hartnoll \& Alvarez, 2003 (Oaxaca State), Macrobrachium tuxtlaense Villalobos \& Álvarez, 1999 (Veracruz State) and Macrobrachium vicconi Roman, Ortega \& Mejía, 2000 (Chiapas State). However, the presence of troglomorphic characters in M. sbordonii to make the diference with these last species that live in surface rivers.

\section{Acknowledgements}

We are grateful to Professor Valerio Sbordoni for giving us the possibility to study this interesting species, for facilities given during the stay of MLM \& LMMO in Tor Vergata University, and for donation most of the type series to the Instituto de Biología of UNAM and to the Laboratorio de Bioespeleología y Carcinología of UQROO. Acknowledges are also extend to all explorers and collectors involved in the speleological expeditions by the Circolo Speleologico Romano. We are grateful to Dr. Donatella Leonardi (Tor Vergata University) for her help in the SEM analysis and to Jorge Canul Sánchez for producing the drawings.

The authors are grateful with DDS of University of Quintana Roo (Mexico) and with Universitá degli Studi di Roma Tor Vergata (Italy) for supporting this collaboration.

\section{Literature cited}

CHONG, S.S.C. (1989). A new species of freshwater prawn, Macrobrachium gua sp. nov. (Decapoda, Caridea, Palaemonidae) from Sabah, East Malaysia, Borneo. Crustaceana, 56(1), 31-38.

GAMBARI, S. \& TOPANI, M. (1986). Descrizioni delle cavitá esplorate. Notiziario del Circolo Speleologico Romano nouva serie, 1, 41-72.

HOBBS H.H. Jr., (1973). Two new troglobitic shrimps (Decapoda: Alpheidae and Palaemonidae) from Oaxaca, México. Bulletin of the Association for Mexican Cave Studies, 5, 73-80.

HOBBS, H.H. III \& HOBBS, Jr. H.H. (1995). Macrobrachium catonium, a new troglobitic shrimp from the Cayo District of Belize (Crustacea: Decapoda: Palaemonidae). Proceedings of the Biological Society of Washington, 108(1), 50-53.

HOLTHUIS, L.B. (1974). Subterranean Crustacea Decapoda Macrura collected by Mr. L. Botosaneanu during the 1973 Cuban-Rumanian Biospeleological Expedition to Cuba. International Journal of Speleology, 6, 231-242.

HOLTHUIS, L.B. (1977). Cave shrimps (Crustacea, Decapoda, Natantia) from Mexico. In: Subterranean fauna of Mexico. Part III, Quaderni Accademia Nazionale dei Lincei, 171, 173-195.

HOLTHUIS, L.B. (1978). Zoological results of the British speleological expedition to Papua New Guinea 1975. 7. Cavernicolous shrimp (Crustacea Decapoda, Natantia) from New Ireland and the Philippines. Zoologische Mededelin- 
gen, 53(19), 209-224.

HOLTHUIS, L.B. (1984). Freshwater prawns (Crustacea Decapoda: Natantia) from subterranean waters of the Gunung Sewu are central Java, Indonesia. Zoologische Mededelingen, 58(9), 141-149.

KEMP, S. (1924). Crustacea Decapoda of the Siju Cave, Garo Hills, Assam. Records of Indian Museum, 26, 42-48.

KOMAI, T. \& FUJITA, Y. (2005). A new stygobiont species of Macrobrachium_(Crustacea: Decapoda: Caridea: Palaeomonidae) from an anchialine cave of Miyako Island, Ryukyu Islands. Zootaxa, 1021, 13-27.

LI, J., CAI, Y. \& CLARKE, A. (2006). A new species of troglobitic freshwater prawn of the genus Macrobrachium from southern China (Crustacea: Decapoda: Palaemonidae). The Raffles Bulletin of Zoology, 54(2), 277-282.

MEJIA, L.M., ÁLVAREZ, F \& HARTNOLL R.G.. (2003). A new species of freshwater prawn, Macrobrachium totonacum (Decapoda: Palaemonidae), with abbreviated development from Mexico. Crustaceana, 76(1), 77-86.

ROMÁN, R., ORTEGA A.L. \& MEJÍA, L.M. (2000). Macrobrachium vicconi, a new species of fresh-water shrimp from a rain forest in southeast Mexico, and comparison with congeners (Decapoda, Palaemonidae). Journal of Crustacean Biology, 20, 186-194.

SBORDONI, V., ARGANO, R. \& VOMERO, V. (1986). Relazione biologica sulle spedizioni "Malpaso" 1981-82 e 1984. Notiziario del Circolo Speleologico Romano, nouva serie, 1, 73-88.

SBORDONI, V., CARCHINI, G. \& LUCARELLI, M. (1987). Primi risultati delle ricerche biospeleologiche svolte nel 1986 e 1987 in Chiapas (Messico). Notiziario del Circolo Speleologico Romano, nouva serie, 2, 135-150.

SBORDONI, V. \& LUCARELLI, M. (1989-90). Racolte biospeleologiche in Chiapas (1988-1991). Notiziario del Circolo Speleologico Romano, nouva serie, 4-5, 55-64.

VILLALOBOS, J.L. \& ÁLVAREZ, F. (1999). A new species of Macrobrachium (Crustacea: Decapoda: Palaemonidae), with abbreviated development, from Veracruz, Mexico. Proceedings of the Biological Society of Washington, 112, 746-753.

WEBER, A., ALLEGRUCCI, G. \& SBORDONI, V. (2003). Rhamdia laluchensis, a new species of troglobitic catfish (Siluriformes: Pimelodidae) from Chiapas, México. Ichthylogical Exploration of Freshwaters, 14(3), 273-280. 